\title{
Depletion of tropical moist forests: A comparative review of rates and causes in the three main regions
}

\author{
Norman Myers (')
}

\begin{abstract}
Information on depletion of tropical moist forests throughout the world is reviewed, including its causes, course and consequences in Latin America, Africa and Southeast Asia. Primary, or undisturbed, forest undergoes varying degrees of perturbation depending on exploitation practices. Timber exploitation has been particularly important in Southeast Asia. Slash-and-burn agriculture often follows due to improved access. Shifting cultivation is especially important in Africa, where high population pressure makes the access roads opened for logging an even stronger catalyst to entran. ce of slash-and-burn farmers. Cattle raising is a major cause in Latin America, often influenced by foreign market pressures and government policies.
\end{abstract}

\section{INTRODUCTION}

Tropical moist forests (TMFs) are undergoing progressive depletion. if present rates of exploitation persist - and they are likely to accelerate - the end of the century may find that extensive sectors of the forests have been grossly disrupted if not destroyed outright. The remaining segments may not survive, except in severely degraded state, beyond another two or three decades. This means that the biome with the richest biotic endowment on earth is being impoverished faster than any other biome (Myers, 1979a and b, and 1980a and b; Persson, 1974, 1975 and 1977; Sommer, 1976; Synnott, 1977; Unesco, 1978; Whitmore, 1975) .

This is not to say, however, that "depletion", "disruption", "degradation" and "impoverishment" are necessarily the same as "final elimination". In another 50 ;ears' time, many of the areas that are presently under primary forest will still feature forest of some kind often secondary forest of various stages of sera! succession, sometimes brush and scrub growth occasionally even a new form of stable climax forest (such as bamboo forest) in those areas where edaphic and climatic factors have been sufficiently altered to foster a different kind of forest. Thus it can be valid to assert, as de certain observers (e.g. Lanly \& Clement, 1979), that the total amount of TMFs of all sorts may not decline nearly os fast as has been proposed for primaly forests. For purposes of this paper, however, the author focuses on those forest formations that are often considered of most interest to the scientist by virtue of their intrinsic biological value, viz. primary forests. These are the forests that have remained more or less undisturbed for appreciable periods - at least. "undisturbed" as compared with the disrupted state imposed by modern man in the recent past.

It is in these primary forests that are to be found the complex ecosystems and diversified relationships of unsurpassed interest. For purposes of basic research, these primary forests appear to be more rewarding than any othei forests. Even marginal modification, such as results from light logging, reduces their value as "living laboratories". So this paper considers that any forest tract that has been disturbed by modern man can no longer be regarded as primary forest; and it is within these terms of reference that the paper assesses the extent of forest depletion in each of the three main regions of the TMF biome.

This is not to say - and the point is stressed - that depletion of TMFs in the sense adopted here is in any way to be deprecated in principle. In certain instances, forests are now exploited in rational sustainable manner, with explicit recognition of consequences entailed. When forests are caused to produce goods and services that contribute to the welfare of all human communities concerned

(1) - Consultant in Conservation and Development, Nairobi, Kenya. 
both now and in the future, this constitutes a "wise use" for the forests in question. To be sure, there are occasions when wise use can lie in preservation of forest tracts for scientific research. But in the main, iegitimate exploitation entails some degree cf disruption for the primary forest - and to the extent that this promotes the general well-being of society now and forever, this action is to be we!comed, just as much as initiatives to safeguard certain forest tracts for scientific research are likewise to be welcomed.

It is frequently observed that there is no one type of TMF. There are many different types. Similarly, there are many different kinds of depletion - different both quantitatively and qualitatively, different according to cause, different according to the challenges they present to conservationists, and so forth. What amounts to a problem in Southeast Asia may not arise in Amazonia, and vice versa. What appears a hopeful prospect in Centra! Africa may not apply in Central America, and vice versa. This paper presents a comparative review of the causes, course, and consequences of forest depletion in each of the three main regions and their several sub. regions.

\section{TIMBER EXTRACTION}

A main reason why forests throughout the world are increasingly exploited is that more people want more wood. The amount of wood that is now cut from all earth's forests totals rather over 2500 million cu. ms., of which around 44 percent is used as timber and for other "solid wood" purposes (two-thirds of it to meet the needs of the developed world). and around 10 percent is manufactured into pulp products (seven-eights for the developed world) (Food and Agriculture Organization. 1978 and 1979a and b). By the year 2000, wood cut for these two categories of use could total about $4000 \mathrm{cu}$. ms.. This will mean growing pressures for exploitation to be directed at the world's forests, and especially at those forests that have been relatively little exploited to date, TMFs. Although they contain abous as much wood as their larger temperate counterparts, TMFs contribute little more than one tenth of the world's wood cut for timber and woodpulp.

The last two decades, however, have witnessed a massive increase in the amount of timber produced and exported from TMF countries, especially Southeast Asia. This has been primarily due to booming demand on the part of developed nations for the type of timber that makes up over 90 percent of TMFs, hardwoods - indeed, as can be seen from Table 1, most of earth's hardiwood forests are located in the tropics. Temperate zone hardwood forests have been steadily depleted, or are coming under greater protection in order to meet environmental interests; and as a result, exploitation pressure is increasingly directed toward tropial forests.

In 1950 the developed world imported 4.2 million $\mathrm{cu}$. ms. of tropical hardwood timber (Table 2). By 1973 the amount had grown to 53.3 million. By 1980 it could well have expanded to 66 million cu. ms., and by the year 2000 to 95 million. Of course, tropical regions utilize a lot of hardwood timber themselves. But the amount has little more than doubled since 1950, whereas developed-world imports have increased 16 times, until the total now exceeds consumption by all tropical countries combined.

The single major source of tropical hardwoods is Southeast Asia (Table 3). Between 1950 and 1976, the region increased its exports 24 times, to account tor three-çuarters of the world market. Latin America, with three times as many hardwood stocks as Southeast Asia, produces only a little uver one fifth of tropical hardwood timber; moreover, the region exports very little due to the difficult location of many of its hardwood forests. Tropical Africa produces a mere one seventh of tropical hardwood timber, though the region has tripled its exports, mainly to Europe, since 1960 .

What is the effect of the harvesting operations that lie behind this growing output of tropical hardwood? How large are the forest areas affected by logging, and do they represent a sizeable proportion of all TMFs? Does logging leave them in a significantly, or even permanently, impoverished state? 
TABLE 1 - Hardwood and So ftwood Forests of The World ('000 square kilometers)

\begin{tabular}{|c|c|c|c|c|}
\hline Region & $\begin{array}{l}\text { Total land } \\
\text { area }\end{array}$ & $\begin{array}{l}\text { Total forests } \\
\text { (and percentage } \\
\text { of land area) }\end{array}$ & $\begin{array}{l}\text { Hardwood forests } \\
\text { (and percentage } \\
\text { of all forests) }\end{array}$ & $\begin{array}{l}\text { Softwood forests } \\
\text { (and percentage } \\
\text { of all forests) }\end{array}$ \\
\hline $\begin{array}{l}\text { All of Asia (except Japan and } \\
\text { U.S.S.R.) }\end{array}$ & 26,320 & $4797(18)$ & $4065(85)$ & $732(15)$ \\
\hline Southeast Asia & 4,640 & $2638(57)$ & $2570(97)$ & $68(3)$ \\
\hline Pacific Area & 8,324 & $868(10)$ & $840(97)$ & $28(3)$ \\
\hline Latin America & 20,100 & $7664(38)$ & $7320(96)$ & $344(4)$ \\
\hline Africa & 29,360 & $6840(23)$ & $6800(99)$ & $40(1)$ \\
\hline North America & 18,532 & $6918(37)$ & $2570(37)$ & $4348(63)$ \\
\hline $\begin{array}{l}\text { Furope (Western Europe } \\
\text { contains over four-fifths } \\
\text { of forests) }\end{array}$ & 4,520 & $1462(32)$ & $610(42)$ & $852(58)$ \\
\hline World & 21,200 & $7194(34)$ & $5464(76)$ & $1730(24)$ \\
\hline Japan & 989 & $228(23)$ & $100(44)$ & $128(56)$ \\
\hline U.S.S.R. & 129,345 & $35,971(28)$ & $11,908(33)$ & $24,063(67)$ \\
\hline
\end{tabular}

(*) - Includes both moist and dry hardwood fcrests; hardwood forest cover 19 milion $\mathrm{km} 2$, of which only around 9 milion are tropical moist forests.

SOURCES: Food and Agriculture Organization, 1978 and $1989 a$ and $b$.

\section{TABLE 2 - Consumption of Tropical Industrial Timber}

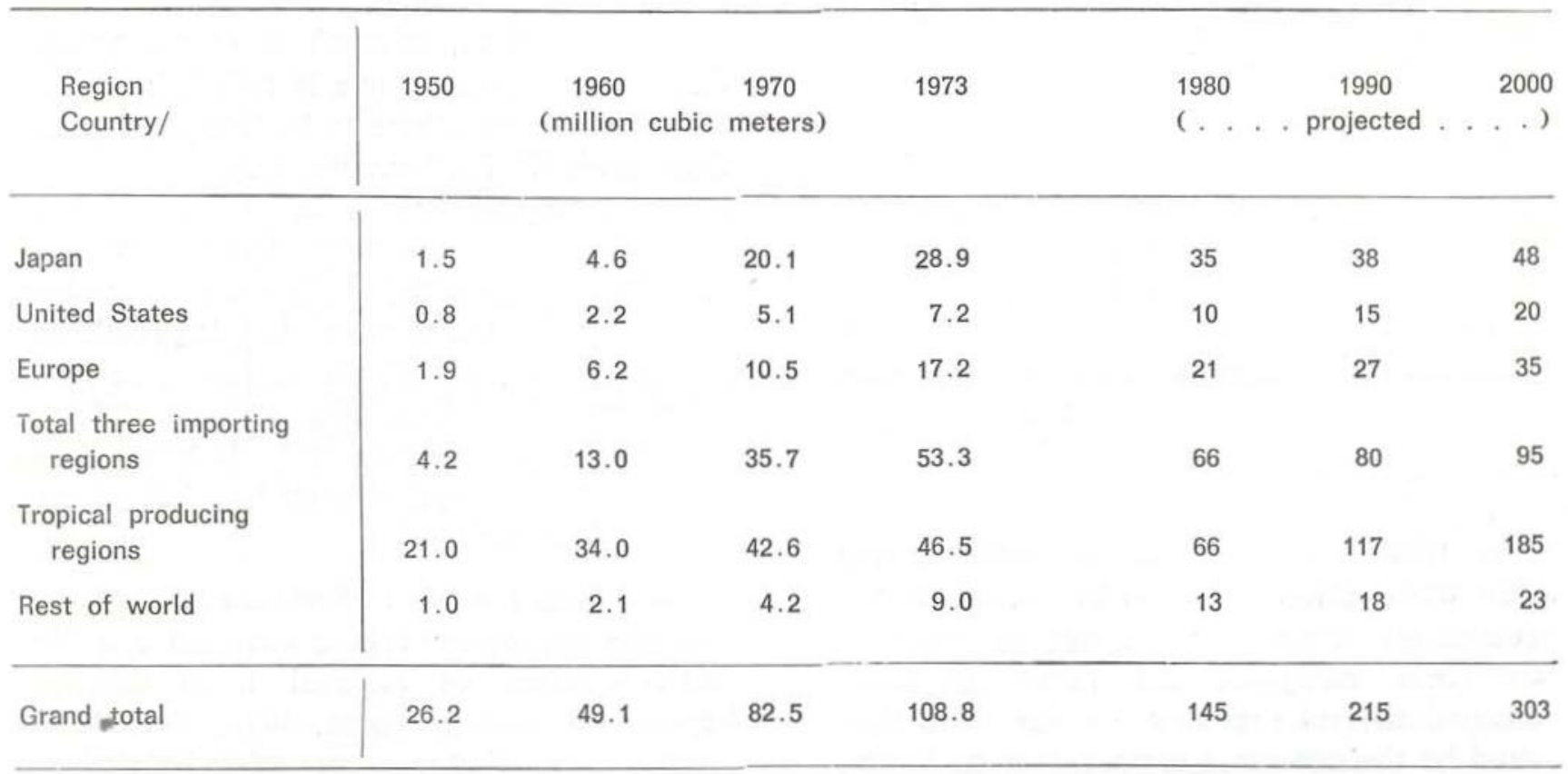

SOURCES: Food and Agriculture Organization, 1979, and 1979a and b.

Depletion... 
TABLE 3 - Supply of Tropical Hard wood Timber, Actual and Projected

(million cubic meters, roundwood log equivalent)

\begin{tabular}{|c|c|c|c|c|c|c|c|c|c|c|}
\hline \multirow{2}{*}{$\begin{array}{c}\text { Region (with area of } \\
\text { hardwood forests in } \\
\text { '000 } \mathrm{km}^{2} \text { ) }\end{array}$} & \multicolumn{2}{|c|}{1950} & \multicolumn{2}{|c|}{1975} & \multicolumn{2}{|c|}{1980} & \multicolumn{2}{|c|}{1990} & \multicolumn{2}{|c|}{2000} \\
\hline & Prod. & $\begin{array}{c}\text { Export } \\
(\%)\end{array}$ & Prod. & $\begin{array}{c}\text { Export } \\
(\%)\end{array}$ & Prod. & $\begin{array}{c}\text { Export } \\
(\%)\end{array}$ & Prod. & $\begin{array}{c}\text { Export } \\
(\%)\end{array}$ & Prod. & $\begin{array}{c}\text { Export } \\
(\%)\end{array}$ \\
\hline $\begin{array}{l}\text { Asia-Pacific } \\
(3200)^{*}\end{array}$ & 14.3 & 2 (14) & 72.5 & $48.5(67)$ & 93 & $65(70)$ & 130 & $82(63)$ & 150 & $80(53)$ \\
\hline $\begin{array}{l}\text { Latin America } \\
(7320)\end{array}$ & 15.5 & $0.8(5)$ & 20 & 3 (15) & 32 & $4(13)$ & 60 & $7(12)$ & 118 & $28(24)$ \\
\hline $\begin{array}{l}\text { Africa } \\
(6800)\end{array}$ & 4.7 & $1.5(32)$ & 16.5 & 11 (67) & 20 & $12(60)$ & 25 & $9(36)$ & 35 & $10(29)$ \\
\hline $\begin{array}{l}\text { Total }(17,320 \text {; } \\
\text { world total } 24,000)^{\circ *}\end{array}$ & 34.5 & $4.3(13)$ & 109 & $62.5(57)$ & 145 & $81(56)$ & 215 & $98(46)$ & 303 & $118(39)$ \\
\hline
\end{tabular}

(*) - Over two-thirds in Southeast Asia.

(*) - North America's hardwood forests account for just over one-tenth of this total

NOTE: As tropical developing countries themselves start to consume more of their hurdwood output, there will be (except in the eventual case of Latin America) a smaller shart available for export to developed countries. At the same time, developed countries demand will steadily expand. So there will be compounded pressure to exploit trcpical hardwood forests.

SOURCES: Food and Agriculture Organization, 1978 and $1979 a$ and $b$.

Due to the diversity of tree species in tropical forests, coupled with the reluctance of international timber markets to take more than a small proportion of wood types available, the commercial logger is inclineo to aim for a highly selective harvest, taking a few choice specimens with disregard for the rest. In short, a "creaming" operation. Of Amazonia's thousands of tree species, only about 50 are widely exploited, even though as many as 400 have some commercial value (Amaya, 1977). Africa exports only 35 principai species (albeit twice as many as in 1950), with 10 accounting for 70 percent of the total (Erfurth, 1976). In Soutneast Asia, loggers focus on less than 100 tree species, with exports consisting mainily of only one dozen or so (Sumitro, 1976; Whitmore, 1975).

So when a patch of TMF is exploited, only a few trees, often less than 20 out of 400 per hectare, are taken. Yet the logging operation can leave many of the remaining trees damaged beyond recovery - far more than would be the case in a temperate zone forest. TMF trees tend to be linked together with vines, lianas and other climbing planis, sometimes as many as 2000 per hectare and some of them $200 \mathrm{~ms}$. long (Ewel \& Conde, 1976). Commercial trees are often limited to those that reach the topmost storey, where, enjoying the sunlight, they develop widespreading crowns, as much as $15 \mathrm{~ms}$. across. When one of these giants is felled, it is likely to cause several others to be broken or pulled down with it. Furthermore, tropical trees are highly susceptible to attack by pathogens; as a result, a minor-seeming injury, such as a patch of bark torn off, can leave a tree vulnerable to irreparable damage. Logging roads and haulage tracks, sometimes averaging as much as $10 \mathrm{kms}$. for each one sq. $\mathrm{km}$. of forest exploited, can, together with dumping zones and iandings for logs, account for $10-30$ percent of the forest area.

Repeated surveys in Southeast Asia reveal that average logging leaves between one third and two-thirds of residual trees damaged beyond recovery (Burgess, 1973; Hadi \& Suparto, 1977; Kartawinata, 1975; Nicholson, 1979; Suparto, 1978; Tinal and Balenewen, 
1974). On top of this, almost one third of the ground may be left bare, in many instances with the soil impacted through heavy machinery. With greater care the damage could be reduced by half. But less disruptive exploitation would raise timber prices for the endproduct consumer - something that the main markets, viz. developed nations, are ostensibly unprepared to accept on the grounds that it would be unduly inflationary.

Clearly, logging impact varies from area to area. In some places, e.g. Amazonia and Central Africa, the consequence is general!y no more than moderate or minor modification of the forest, while in other places it amounts to gross degradation. Where the disruption is marginal, the forest may restore itself to primary state within just a few years, perhaps one decade or so. Where the disruption is more marked, the forest may take several decades to recover, and the ensuing ecosystem may remain qualitatively different from the original one for a whole century, if not longer.

What then, is the overall impact of logging on TMFs? It is difficult to arrive at any firm conclusion, due to the huge and dispersed areas involved, and due to the lack of docu. mentation on which to base a solid assessment. Nevertheless, for purposes of coming to grips with trends of disappearing forests it is appropriate to come up with some kind of answer, even if little better than an informed guesstimate". During the 10 years 1964-73, the afrected area in Africa grew by 33 percent, in Latin America by 46 percent, in Southeast Asia by 144 percent and in the tropics as a whole by 78 percent. The area in question totalled somewhere between 460,000 and $720,000 \mathrm{~km}^{2}$ (Myers, 1979a and b; Sommer, 1976). The area of forest in Southeast Asia that was being newly affected each year in the mid-1970s amounted to $10,000-27,000$ $\mathrm{km}^{2}$; in Latin America, 8,000-25,000 $\mathrm{km}^{2}$; and in Africa (mostiy West Africa), $32,000 \mathrm{~km}^{2}$. This made a total for the tropics of 53,000 $-87,000 \mathrm{~km}^{2}$. Moreover, these figures refer only to legal fellings of industrial timber; illegal fellings could swell the totals a good deal more (as in Thailand and Indonesia where "timber poaching" is a great and growing porblem), sometimes by twice as much.

\section{SLASH-AND BURN CULTIVATION}

The logging impact can be grossly aggravated by what happens after the commercia! exploiter leaves his patch of forest. Along the timber tracks ccme subsistence peasants, able to penetrate deep into forest areas that have hitherto been closed to them. Clearing away more trees in order to plant their crops, they may soon cause far more damage and destruction that the lumber man did. Not only do they arrive in iarge numbers, mut they stay in the locality permanently.

Not that the slash-and-burn cultivator has always been destructive. Before he became so numerous, he could operate as a shifting cultivator. He would fell and burn a patch of forest, raise crops for two or three years until the soil lost its fertility, or until weeds moved in, then he would move on and repeat the process in another part of the forest. This was a style of agriculture that aliowed the cultivator to make sustainable use of the forest environment. As long as there were not more than four or five persons per square kilometer, and a patch of farmed forestland could be left fallow for at least ten years in order to renew itself, the system worked (Clarke. 1976; Denevan, 1977 and 1978; Food and Agriculture Organization, 1974; Greenland \& Herrera, 1977; Hauck, 1974; Kundstadter et al., 1978; Sanchez, 1976; Watters, 1971) .

Now, however, the situation has changed. Cultivators have increased in numbers to a point where there are often three times as many people per square kilometer; and they find themselves with less space to move around in. The result is that they make intensive as well as extensive ciemands on the forest, leaving local ecosystems with little chance to recover.

In adidition, these traditional farmers are now being joined by large communities of subsistence peasants, who, due to lack of land elsewhere, are moving into forests where they aciopt a slash-and-burn style of agriculture that leaves even less scope for forest regeneration. These recent arrivals, possessing little cultural adaptation to forest environments, tend to advance upon the natural forest 
in waves: they operate as "pioneer fronts" pushing ever-deeper into forest tracts, leaving behind them a mosaic of degraded croplands and brush growth where there is no prospect of a natural forest re-establishing itself, even in impoverished secondary form.

All in all, these forest farmers have been estimated in the mid-1970s to total at least 140 miliion persons, occupying some 2 million sq. kms. (or over one-fifth) of the TMF biome (King \& Chandler, 1978; Myers, 1979a and b; Pers:son, 1975 and 1977; Sommer, 1976). Some 50 million are considered to be occupying at least 640,000 sq. kms. (a Texas-sized area) of primary forest, while another 90 million exploit twice as much land in secondary forests. According to preliminary reckonings, these cultivators are believed to eliminate at least $100,000 \mathrm{sq}$. kms. of forest each year. The greatest loss occurs in Southeast Asia, where farmers clear a minimum of $85,000 \mathrm{sq}$. $\mathrm{kms}$. each year (some of which are allowec to regenerate), adding to 1.2 million sq. $\mathrm{kms}$. of formerly forested croplands in the region (Chandrasekharan, 1978; Kartawinata, 1975). Tropical Africa is believed to have lost one million sq. kms. of moist forest to these culti. vators before the arrival of modern develop. meni patterns in the last quarter century; of Africa's present TMF expanse, as much as $400,000 \mathrm{sq}$. kms. may now be under this form of agriculture, with a current loss of forest estimated at 40,000 sq. kms. per year (Aubreville, 1947; Braun, 1974; Food and Agriculture Organization, 1974; Hauck, 1974; Persson, 1977; Sommer, 1976). A similar story applies in Latin America, though fewer details are available; all forms of expanding agriculture in Latin America, of which slash-and-burn is a major type, are thought to be accounting for $50,000 \mathrm{sq}$. kms. a year (Denevan, 1977 and and 1978; Watters, 1971).

How much reliability can be placed on these statistical estimates? A question difficult to evaluate. We can, however, make a comparative assessment by coming at the problem from a different direction. There is good reason to believe that the figure mentioned above, 140 million forest farmers, represents a minimum number. At an average size of 7 persons to a family (a roughly acceptable figure for Indonesia, Philippines, Thailand, Central America and Colombia), this means there are some 20 million families. If each family clears one additional hectare each year. as seems to be regular practice, this means that foerst farmers are clearing some 200,000 sq. kms. of forest each year. True, a good number of these farmers exploit secondary forests; and in certain sectors of primary forest, e.g. in Central Africa, population densities are still low enough to permit sus tainable use of the forest with prospect of eventual regeneration of primary vegetation. But so far as the author can determine, having discussed the subject with several dozen experienced observers in 26 countries of the TMF biome (see also references above), it is not unrealistic to suppose that forest farmers are converting at least $100,000 \mathrm{sq}$. kms. of primary forest to permanent cultivation each year.

These figures represent minimal estimates, prepared through order-of-magnitude reckonings. A further assessment can be arrived at through looking at the consequences of com. mercial logging, viz. the amount of forest accounted for by cultivators who move into unsettled territories after the logger has quit the scene. Fielci investigations in Ivory Coast indicate that for every $5 \mathrm{~m}^{3}$ of loge removed by the timber exploiter, one hectare of forest disappears at the hands of the follow-on cultivator (Lanly, 1969). What happens in Ivory Coast can be said to apply broadly in other parts of West Africa with their high-density popuiations; it is unlikely to apply in Congo, which, with an area similar to Ivory Coast's but with only one seventh as many people, is under less pressure from spreading agriculturalists. Similar differentiation holds good for various sectors of Southeast Asia, Amazonia and Central America.

To take a general overview, Africa in 1973 produced 31.2 million $\mathrm{m}^{3}$ of logs, Southeast Asia 81 million, and Latin America 25.5 million. Together with smaller amounts elsewhere, this makes a total for the tropics of 149 million. Using the very rough rule of thumb developed in Ivory Coast, this could 
mean that, in the areas in question, 62,400 , $162,000,51,000$ and $298,000 \mathrm{~km}^{2}$ of forest were eliminated by slash-and-burn cultivators. The last tigure, almost $300,000 \mathrm{~km}^{2}$ for the tropics, compares with a minimal estımate of 100,000 $\mathrm{km}^{2}$ through the preceding calculation. Because of differentiated impact, the figure of 300,000 $\mathrm{km}^{2}$ is probably way too high, while 100,000 $\mathrm{km}^{2}$, being a minimal conservative estimate, could be decidedly too low.

\section{Cattle raising}

A major cause of forest elimination in Latin America is cattle raising (Fearnside, 1979). The phenomenon is already widespread in Central America, Brazil, México, Colombia and Peru, while Bolivia plans to convert extensive sectors of forest into man-established pasturelands. Indeed it looks likely that cattle raising could grow to rank as the main cause of forest elimination in Latin America. In Africa and Southeast Asia, by contrast, the factor hardly arises at all.

Catt'e raising does not amount to moderate modification of primary forest, as is often the case with timber harvesting and sometimes the case with forest farming. It amounts to fundamental transformation: the forest is cleared away entirely, and on a scale that will not allow for recolonisation by adjacent forest if the pastureland is abandoned. In fact it often occurs that ranches remain productive for as little as 6-10 years, then are taken over by scrub growth. The ranch does not generally mind, since he can move on to another patch of forest and start again. Hence a generic term for this kind of forest exploitation could be "shifting ranching".

The practice has been established in Central America for at least 30 years. During that period, the extent of artificial pasturelands and the numbers of beef cattle have more than doubled Dwoskin, 1975; Foreign Agricultura! Service of USDA, 1976; Myers, 1979a and b; Parsons, 1976) - an expansion that has occurred almost entirely at the expense of primery forests, of which some 70 percent have now been cleared, possibly more. A salient example lies with Costa Rica where the industry seems to be more developed than elsewhere. In 1950, Costa Rica's pasturelands accounted for one eighth of the country, but by 1975 they had expanded to one third, and by 1980 they may cover as much as 40 percent; at a present clearing rate of $500 \mathrm{sq}$. kms. per year, they will have eliminated primary forests outside parks by 1990. In 1960, Costa Rica's cattle herds totalled slightly over 900,000 ; by 1976 they had increased to 1.9 million; by 1980 they are projected to reach 2.4 million (for Central America as a whole, figures are 5.6 milion in 1960, 9.2 million in 1970 and 12.9 million in 1980). During the past two decades, Costa Rica's beef production has been growing at rates between 5 and 9 percent per year; at the same time, however, local consumption of beef has generally been declining until it has stabilized around $8-10 \mathrm{kgs}$ per head per year (by comparison with 55-60 kgs. in the United States). Virtually all extra output of beef in Costa Rica has been consigned to export markets, approaching 50 million kgs. of beef per year; the bulk, some 60 percent, goes to the United States. A simılar pattern obtains for Central America as a whole: while not such a great proportion of beef output is despatched overseas, the share going to the United States averages 66 percent. For further details, see Tables 4 and 5 .

It is illuminating to see just what happens to the beef when it reaches the United States. According to the Grupo Ganaciero Industria da Costa Rica (a ranchers' organisation) and the Meat Importers Council of America, most of it makes its way into the hamburger and frankfurter trade. From the early 1960s, fast-food chains in the United States have boomed, until they grew during the mid-1970s by 20 percent per year, or $2 \frac{1}{2}$ times as fast as the restaurant industry overall. Over half of all sales a:e now accounted for by only eight firms, notably the major hamburger corporations. The largest, Macdonalds, sells 3 billion hamburgers each year with total sales worth $\$ 3$ billion; in the process, it accounts for the equivalent of 300,000 head of cattle.

As a result of this booming business, the fast-food trade has looked for additional supplies of meat, finding a source of cheap 
TABLE 4 - Central America Exports of Beef

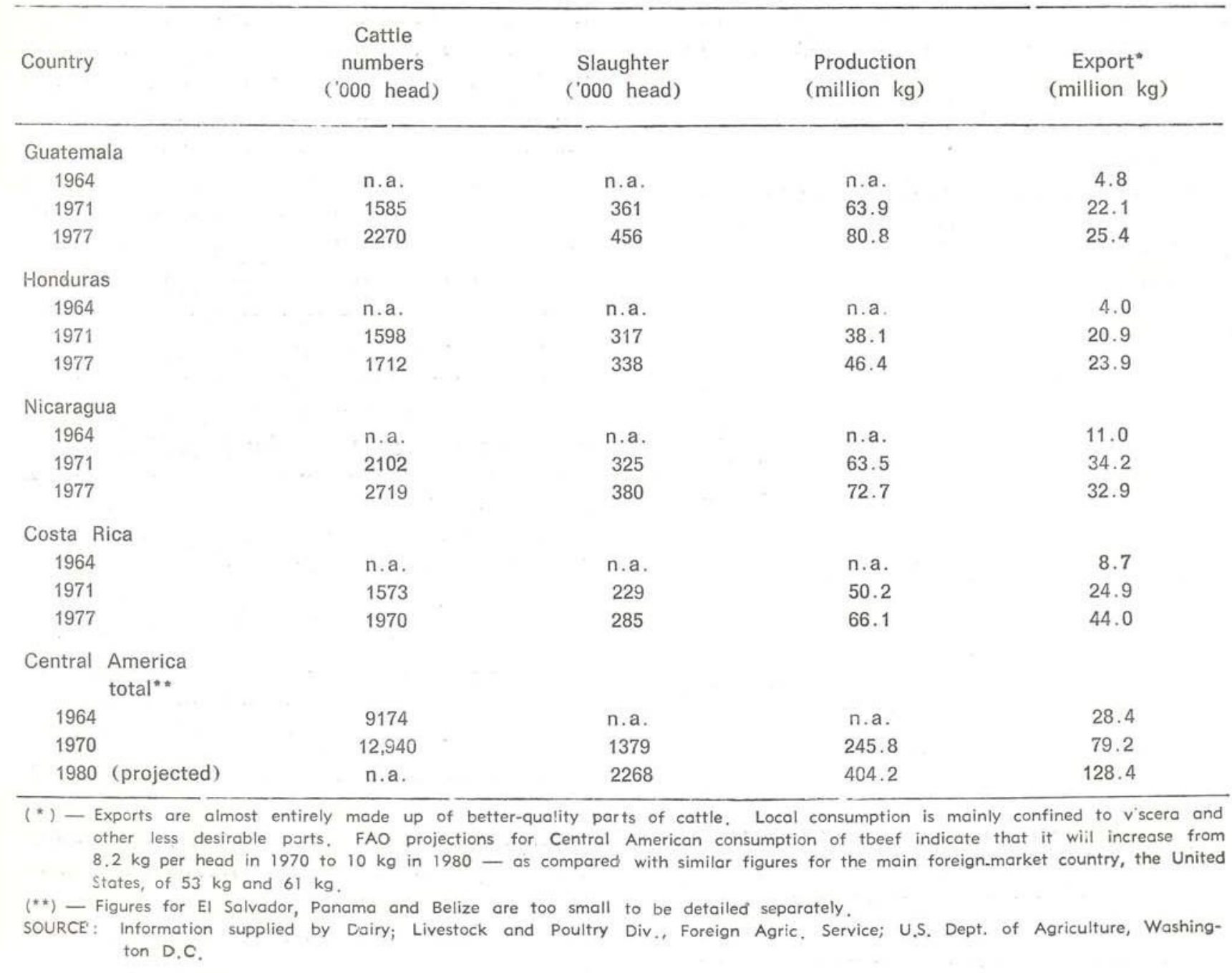

beef in Central America. The beef is "cheap" only in relation to supplies within the United States, which, with high land and labor costs, is over twice as expensive as beef grown in Costa Rica. Thus the price of a U.S. hamburger does not reflect the environmental costs of its production in Central America. The American consumer, seeking a good-quality hambur. ger at "reasonable", i.e. non-inflationary, price, is not aware of the spinotf consequences of his actions far away from his homeland.

The beef-import trade is of considerable benefit to the United States. it generates sizeable profits for the U.S. corporations invoived, and it enables the American consumer to enjov ample supplies of cheap beef. Beef imported from Central America in 1978 averaged $\$ 1.47$ per $\mathrm{kg}$, compared with a wholesale price of $\$ 3.3$ for grass-fed beef produced in the United States. Even more important, the cost of U.S. beef has been climbing far faster than the overall cost of living. This is partly due to American's insati. able demand for beef, and partly due to declining numbers of American cattle from 132 million in 1976 to 116 million in 1978 (stockmen have been disposing of their cattle on the grounds that they could not make sufficient profit). During the first 5 months of 1978 beef prices jumped by 35 percent, and in the first part of 1979 they soared in like manner. Faced with these calamitous increases, the U.S. government decided to step up beef imports by 7.6 percent in mid-1978 and by a further 5 percent in early 1979 . Although these measures contributed less than 1 percent to the country's consumption of beef, the government estimated they woula 
trim one nickel off the price of a hamburger. Hardly any other initiative, it was said, could do as much to stem inflation - and nothing was said about what the measure would do to Central America's forests.

TABLE 5 - U.S. Imports of Beef

\begin{tabular}{|c|c|c|}
\hline & 1971 & 1976 \\
\hline Country of origin & ('000 of kg) & ('000 of kg) \\
\hline Guatemala & 14,955 & 15,486 \\
\hline Honduras & 15,066 & 18,430 \\
\hline Costa Rica & 18,648 & 25,416 \\
\hline Nicaragua & 23,869 & 22,670 \\
\hline Mexico & n.a. & 18,040 \\
\hline Brazil & 28,631 & 33,196 \\
\hline $\begin{array}{l}\text { Total, from all } \\
\text { countries }\end{array}$ & $\begin{array}{l}595,751^{\circ} \\
\text { (of which Aus- } \\
\text { tralia and New } \\
\text { Zealand } \\
431,781 \text { ) }\end{array}$ & $\begin{array}{l}675,522 \\
\text { (of which Aus- } \\
\text { tralia and New } \\
\text { Zealand } \\
339,625 \text { ) }\end{array}$ \\
\hline
\end{tabular}

NOTE: The Meat Importers Council of America states that bulk of these imports go into processed meat products, notably hamburgers, frankfurters and other convenience foods.

(*) - Amounts to about 1 percent of U.S. domestic production. SOURCE: Information supplied by Dairy, Livesttock and Poultry Division, Foreign Agricultural Service, U.S. Department of Agriculture, Woshington, D.C.

A somewhat related strategy has been attempted by Brazil, though with a different outcome to date (Alvim, 1977; Berutti, 1978; Pandolfo, 1978, Reis, 1978). During the 1970s, Brazil tried to expand its beef production rapidly, with the eventual aim of becoming one of the world's leading beef exporters by the early 1980s. This latter goal has now been shelved to a later date, but Brazil still seems committed to boosting cattle ranching as a mode to exploit, or at least to settle, extensive sectors of Amazonia. Between 1966 and 1979, more than 300 ranches have been established, under the auspices of the Superintendency for Development of Amazonia (SUDAM); these ranches have caused the conversion of at least $80,000 \mathrm{sq}$. kms. of forest into pasturelands, supporting some 6 million head of cattle (an average of one animal to 1.3 hectares). In addition, another 20,000 ranches of smaller scale have been established.
Interesting enough, a number of the largest ranches in Brazilian Amazonia are set up through foreign capital. A U.S. consortium of Brascan-Swift-Armour-King Ranch holds around $720 \mathrm{~km}^{2}$, with an investment of $\$ 6$ million. Other multinational corporations include Heublein, Sifco Industries, and Twin Agricultural and Industrial Developers from the United States, Mitsui, Tsuzuki Spinning, and Nichimen and Grubo Bradesco from Japan, Liquigas from Italy, and George Markhof from Austria, among many more from industrialized nations. Investment on the part of the twelve largest enterprises totals \$21 million, except for Volkswagen with \$35 million, (Davis, 1977; Irwin, 1977). Volkswagen believes that although people may come to purchase fewer cars in the wake of the oil price hike, they will hardly be inclined to eat less beef. Volkswagen holds a concession of $1400 \mathrm{~km}^{2}$ in the eastern Amazon, of which half is to be converted into pastureiand. To date the Company has burned over $100 \mathrm{~km}^{2}$ of forest, enough for a herd of 10,000 cattle. The eventual aim is to increase the grasslands to $700 \mathrm{~km}^{2}$, to support 120,000 cattie.

in both Brazil and Central America, however, raising beef in tropical forestlands is not so straightforward as it might seem Kirby. 1976; Osbourn, 1975; Smith, 1976 and 1978). Stocking rates are low, a mere one animal per hectare. Steers take 4 years before they are ready for slaughter, at a weight of $450 \mathrm{~kg}$. Soils quickly become exhausted of nutrients, and pastures feature poorer and poorer grass unless they receive ever-growing amounts of fertilizer. A good number of ranches have already been abandoned, and hundreds more look likely to become unprofitable after only 5 years. Due to a spreading problem of toxic weeds, it is not unusual for a ranch to lose one fifth of its cattle.

it is ironic that in both Brazil and Central America, much more beef could be raised, at far lower environmental cost, on existing pasturelands in other parts of the countries concerned. It has even been suggested that cattle husbandry could probably be made 4 or 5 times more efficient, and meat output increased 10 times, merely through improved 
breeds of livestock and prophylactic drugs to counter epizootics, plus better management all round. This would enable the countries in question to produce all the extra beef they want without eliminating a single additional rainforest tree. There is little inducement, however, for the countries' large landowners in some cases, a mere 10 percent of all landowners control 80 percent of the land) to aim for intensive management of their holdings outside the forest zones as long as they encounter powerful financial persuasion to clear new territories in primary forest areas. To the wealthy stockman who obtains forestland for next to nothing, it matters little that he needs 10 times as much space to raise his cattle herds than in other areas where typical pastures lose only 30-40 percent of initial stocking capacity after 20-30 years. The upshot is that in the countries in question (as in many parts of the tropical developing world), stock raising remains one of the most wasteful of al! agricultural industries.

it is this factor of beef exports that, as is the case with the trade in tropical hardwoods, poinis up the relationship between developedworid lifestyles and changes overtaking developing-world environments. As beef produced in Europe and North America grows more expensive, the affluent consumer stimulates the spread of ranching into forest zones of tropical America. He does not do it wittingly and certainly not with wanton intent. But he does it effectively and increasingly. The relationship could become more pronounced in view of FAO projections to the effect that developed-world demand for beef will rise more rapidly until at least 1990 than for any other food category except fish.

As the international beef trade grows. more countries of Latin America, notably Peru and Colombia, aim to convert portions of their Amazonian lowland forests into cattle ranches. Bolivia hopes to open up its sparsely populated eastern region. an area larger than Spain, through an initiative on the part of the Angro-Bolivian Land and Cattle Company, which plans to obtain financial support from Britain the United States, West Germany and France. Bolivia intends to sell off almost 1 million hectares of virgin forest, at a mere $\$ 42$ per hectare, to 150,000 white settlers whom it hopes to attract from southern Africa.

What, then, is the overall impact of cattle raising on TMFs? Between 1962 and 1985, it is expected that at least $325,000 \mathrm{~km}^{2}$ of Latin America's tropical forests, or an area the size of Norway or New Mexico, will have been cleared for pasturelands (Brazil, 125,000, and Colombia, 66,000). This works out at an average of just under $13,500 \mathrm{~km}^{2}$ per year. Since the rate is likely to be greater at the end of the period than at the start, due to growing population pressures if nothing else, the figure for 1980 could well have reached $20,000 \mathrm{~km}^{2}$.

\section{Summation AND CONCLUSION}

Such are the nature and scope of some factors that contribute to disruption and elimination of TMFs. Two major conclusions emerge.

The first is that, at present rates of exploitation, which are likely to accelerate, certain countries and regions seem to have little prospect of retaining much undisturbed TMF by 1990. Among these countries and regions are Philippines and Thailand in Southeast Asia, plus possibly Peninsular Maiaysia; most of West Africa; and most of Central America (alsc certain other countries whose forests present exceptional biological interst but that have not been considered in this paper on the grounds that they lie outside the main TMF zones in question; notable examples are Madagascar, Kenya, Tanzania, Sri Lanka, and New Caledonia - all countries with remarkably high levels of species endemism). A similar prospect seems to lie ahead, by the end of the century, for Sabah and Sarawak in Malaysia, for most if not virtually all of Indonesia, much of Papus New Guinea, and most if not virtually all of Cameroon. By contrast, it seems distinctly possible if not probable that large tracts of TMF will remain more or !ess untouched in the Zaire Basin and in northwestern Amazonia (except for those sectors lying in Colombia and Peru) . 
The second conclusion is the types and patterns of exploitation are highly differentiated. In Southeast Asia, the main factor is the timber harvester, sometimes etxracting 80-140 cu. ms. of timber per hectare, or 15-25 percent of total standing timber - leaving behind 2 basically different kind of forest. This heavy impact of logging is aggravated by the follow-on cultivator. In West Africa, the timber harvester removes a mere $10-25 \mathrm{cu} . \mathrm{ms}$. per hectare, thus his impact is far less critical. But, due to bigh population, pressures in countries concerned, the logger plays a key catalytic role in opening up forestlands for huge throngs of forest farmers. In Latin America, the timber exploiter generally takes an even lighter harvest than in West Africa, so his impact is still more moderate if not marginal; his operations are far less extensive; and except in a few localities, he plays next to no part in fostering incursions by forest farmers. But in Latin America the cattle rancher is already a major factor in elimination of forests.

Will these patterns persist into the future? Can we expect that the next two decades will prove to be "the same as before, only more so"? Or can we anticipate a shift in patterns? So far as this writer can discern from an extremely hazy crystal ball, and having assessed the situation through repeated visits to almost all countries in question, a few changes can reasonably be surmised. If Southeast Asia's dipterocarp forests continue to be over-exploited, the timber stocks there will rapidly decline to somewhere near exhaustion - which will transfer exploitation pressures to other parts of the TMF biome, e.g. the more accessible parts of Amazonia and the Zaire Basin. This trend will be assisted by new technology, notably "any tree/all tree" harvesting via wood-chip processing, thus enabling greater use to be made of the highly heterogeneous forest formations of Amazonia and of the many tree species in Central Africa that have hitherto proved unattractive to commercial, markets. In turn, the expansion of timber harvesting will stimulate the flood of landless peasants into forests (by far the mos! threatening prospect for TMFs), unless a means can be devised to tackle the problem presented by hundreds of millions of would-be forest farmers, through e.g. agroforestry (a strategy that encourages cultivators to plant trees rather than cut them down). Thirdly, it seems plain that demand for beef is going to continue to climb through the roof, both on the part of developed-world consumers with their excessive appetites and on the part of developing-world consumers who surely deserve a more nutritious diet than they presentiy receive. As Japan, for example, finds that marine sources of anima! protein continue to decline, and as Japanese seek to enjoy more beef anyway, we may see Mitsubishi and Sumitomo go into the business of cattle raising on those forestiands in Southeast Asia from which they have already derived a huge harvest of timber.

We could even find that TMFs are subjected to forms of utilization that do not yet rank among major types of land use. In the wake of deforestation-caused debacles in all parts of the biome, forests may come to be valued for their environmental services such as watershed protection, as much as for their material goods such as timber. In the wake of OPEC price rises, forests may come to be expioited as sources of bio-energy - after all. TMFs are unmatched as natural generators of plant biomass for pyrolisation into alcohol fuels. Also as a consequence of OPEC's price hikes, which are placing petroleum beyond the reach of petro-chemical industries, TMFs may start to supply feedstocks of phyto-chemicals: with almost half of earth's 5-10 million species, less than one percent of which have been intensively screened for their utilitarian benefits, it seems a not unlikeiy prospect that TMFs will provide all manner of genetic resources for lise as drugs and other medica. tions (TMF plants already supply several potent anti-cancer drugs, startpoint materials for more effective and safer contraceptive pills, and a host of other important items in the pharmaceutical trade - a commerce that is now worth, in terms of sales to end-product consumers world-wide, several billion dollars per year (Myers, 1978, 1979a)) . 
Indeed, it would be a welcome prospect if TMFs were to be exploited for the high-value products they have to offer. Extraction of phyto-chemicals, for instance, could prove an exceptionally selective mode of exploitation. leaving the forest virtually undisturbed. It is by virtue of their vast stocks of unique raw materials that TMFs represent some of the most valuable natural resources with which society can confront the unknown challenges of the future. What a change in exploitation patterns it woult represent, were TMFs to be utilized in ways that produce most benefits for most people, now and forever. It could amount to the most rational, and the least disruptive. form of exploitation in view.

Whatever lies ahead, it would be a rash conjecture to suppose that the future for TMFs will amount to a simple extrapolation of the present.

\section{RESUMO}

Informações sobre a depleção das florestas úmidas tropicais no mundo são revisadas, inclusive das suas causas, tendências e conseqüências na América Latina, Africa e Suleste da Ásia. Floresta primária, ou seja não perturbada, sofre diferentes graus de mudança dependendo das práticas de exploração. Exploração de madeira tem sido particularmente importante no Suleste da Ásia. Agricultura itinerante muitas vezes segue devido ao acesso melhorado. Agricultura migratória é especialmente importante na Africa, onde pressão populacional alta faz com que estradas de acesso abertas para a retirada da madeira se tornam um catalisador ainda mais forte, levando à entrada de agricultores itinerantes. Pecuária é uma causa principal na América Latina, muitas vezes influenciada por pressc̃es de mercados estrangeiros e por políticas governamentais.

\section{REFERENCES}

ALVIM, P. de T.

1977 - The Balance Between Conservation and Utilization in the Humid Tropics, with Special Reference to Amazonia Brasii. In: G.T. Prance \& T.S. Elias, eds. Extinction is Forever. New York. New York Botanical Garden, 347. 352.

AMAYA, S.

1977 - Wood - The Neglected Resource. Report, 6 (1): $8-9$.
AUBREVILLE, A.M.A.

1947 - The Disappearance of the Tropical Forests of Africa. Unasylva, 1 (1): 5-11.

BERUTTI, P.A.

1978 - Desenvolvimento da Amazônia Impoe Uma Politica Global y Unica, Que Se Sobreponha as Divergências Setoriais. Instituto Brasileiro de Desenvolvimento Florestal, Brasília, Brazil.

BRAUN, $\mathrm{H}$.

1974 - Shifting Cultivation in Africa. Report of the FAO/SIDA/ARCN Regional Seminar of Shifting Cultivation and Soil Conservation in Africa. Rome, Italy. Food and Agriculture Organization.

BURGESS, P.F.

1973 - The Impact of Commercial Forestry on the Hill Forests of the Malay Peninsula. Proceedings of Symposium on Biological Resources and Natural Development, Biolndo. nensia, 1: 17-23.

CHANDRASEKHARAN, C. (ed.)

1978 - Shifting Cultivation. Forest News, 2 (2): $1-25$.

CLARKE, W.C.

1976 - Maintenance of Agriculture and Human Ha. bitats within the Tropical Forest Ecosystem. Human Ecology, 4 (3): 247-259.

DAVIS, S.H.

1977 - Victims of the Miracle: Development and the Indians of Brazil. New York. Cambridge University Press.

DENEVAN, W.M.

1977 - The Causes and Consequences of Shittirg Cultivation in Relation to Tropical Forest Survival. Paper presented to International Congress of Latin-American Geographers, Paipa, Colombia, August 3-9 1977. Department of Geography, University of Wisconsin, Madison, Wisconsin. 16p momeo.

1978 - The Role of Geographical Research in Latin America. C.L.A.G. Indiana, USA. Publications, Muncie.

DWOSKIN, P.B.

1975 - Fast Food Franchises: Miarket Potentian for Agricultural Products in Foreign and Domestic Miarkets. Washington D.C. Economic Research Service, U.S. Department of Agriculture.

ERFURTH, T,

1976 - Toward the Wider Use of Tropical Wood Products. Unasylva, (112 and 113): 119-126.

EWEL, J. \& CONDE, L.

1976 - Potential Ecological Impact of Increased Intensity of Tropical Forest Utilization. Madison, Wiscosin. Forest Products Laboratory. 
FEARNSIDE, P.M.

1979 - O Desenvolvimento da Floresta Amazônica: problemas prioritários para a formulação de diretrizes. Acta Amazonica, 9 (4) suplemento: 123-129.

FOOD and Agriculture Organization

1974 - The State of Food and Agriculture. Rome, Italy. Food and Agriculture Organization.

1978 - Yearbook of Forest Products 1977. Rome, Italy. Food and Agriculture Organization.

1979a- Agriculture: Toward 2000. Rome, Italy. Food and Agriculture Organization.

$1979 \mathrm{~b}$ - Chaepter on Forestry and Rural Development, for State of Food and Agriculture 1979 (draft). Rome Italy. Food and Agriculture Organization.

FOREIGN Agricultural Service of U.S.D.A.

1976 - Costa Rica: Agricultural Situation. Washington D.C. U.S. Department of Agriculture.

GREENLAND, D.J. \& HERRERA, R.

1977 - Patterns of Use of Tropical Forest Ecosystems: Shifting Cultivation and Other Agricultural Practices. France, Paris. State of Knowledge Report, UNESCO.

HADI \& SUPARTO, R.S. ed.

1977 - Proceedings of Symposium on the Long. Term Effects of Logging in Southeast Asia. Bogor, Indonesia. Regional Center for Tropical Biology.

HAUCK, F.W.

1974 - Shifting Cultivation and Soil Conservation in Africa. Soils Bulletin n. 24 Rome, Italy. Food and Agriculture Organization.

IRWIN, H.S.

1977 - Coming to Terms with the Rain Forest. Garden, 1 (2): 29-33.

KARTAWINATA, $K$.

1975 - The Exploitation of Natural Forests and Natural Areas Development. Bio Indonesia, 1: 17-23.

KING, K.F.S. \& CHANDLER, T.

1978 - Wasted Lands. Nairobi, Kenya. International Center for Research in Agroforestry.

KIRBY, J.M

1976 - Agricultural Land Use and The Settlement of Amazonia. Pacific Viewpoint, 17 (2): 105-132.

KUNSTADTER, P.; CHAPMAN, E.C. \& SABHASRI, S. eds. 1978 - Farmers in the Forest: Economic Develop. ment and Marginal Agriculture in Northern Thailand. Honolulu, Hawaii. University Press of Hawaii.

LANLY, J.P.

1969 - La Regression de la Foret dense en Cote d'Ivoire. Bois et Forests des Tropiques, (127): 45-59.
LANLY, J.P. \& CLEMENT, J.

1979 - Present and Future Forest and Plantation Areas in the Tropics. FO: MISC/79/1. Rome, Italy. Food and Agriculture Organiza. tion.

MYERS, N.

1979a - The Sinking Ark. Oxford and New York. Pergamon Press.

$1979 \mathrm{~b}$ - Survey of Conversion Rates of Tropical Moist Forests: Report to National Academy of Sciences. Washington D.C. National Research Council.

1980a - Conversion of Tropical Moist Forests: Causes, Course and Consequences. In: F.B. Golley, ed. Tropical Rainforests. New York. Structure and Function, Elsevier Press (forthcoming).

1980b- Present Status and Future Prospects of Tropical Moist Forests. Environmental Conservation (forthcoming).

NICHOLSON, D.I.

1979 - The Effects of Logging and Treatment on the Mixed Dipterocarp Forests of Southeast Asia. Report $\mathrm{FO} / \mathrm{MISC} / 79 / 8$. Rome, Italy. Food and Agriculture Organization.

OSBOURN, D.F.

1975 - Beef Production from Improved Pastures in The Tropics. World Review of Animal Production, 11 (4): 23-31.

PANDOLFO, C.

1978 - A Floresta Amazônica Brasileira. Brasília. Departamento de Recursos Naturais, Superintendência do Desenvolvimento da Amazônia. Ministry of the Interior.

PARSONS, J.J.

1976 - Forest To Pasture: Forest Development or Destruction ? Revista de Biologia Tropicale, 24: 121-138.

PERSSON, R.

1974 - World Forest Resources. Research Notes N. 17. Stockholm, Sweden. Royal College of Forestry.

1975 - Forest Resources of Africa, Part I: Country Descriptions. Department of Forestry Survey, Research Notes N.: 18. Stockholm, Sweden. Royal College of Forestry.

1977 - Forest Resources of Africa, Part II: Regional Analysis. Stockholm, Sweden. Department of Forest Survey, Research N.:22, Royal College of Forestry.

REIS, M.S.

1978 - Uma Definição Technico-Politica para o Aproveitamento Racional dos Recursos Florestais da Amazônia Brasileira. Brasília. Instituto Brasileiro de Desenvolvimento Florestal. 


\section{SANCHEZ,}

1976 - Properties and Managment of Soils in the Tropics. New York. John Wiley.

SMITH, N.J.H.

1976 - The Transamazon Highway: A Cultural and Ecological Analysis of Settlement in the Humid Tropics. PH. D. Dissertation, University of California Berkeley, California.

1978 - Agricultural Productivity Along Brazil's Transamazon Highway. Agro-Ecosystems, 4: 415-432.

SOMMER, A.

1976 - An Attempt at an Assessment of the World's Tropical Moist Forests. Unasylva, 28 (112-112): 5-24.

SUMITRO, A.

1976 - Foreign Investment in the Forest-Based Sector of Indonesia: Increasing its Contribution to Indonesian Development. Yogykarta, Indonesia. Faculty of Forestry, University of Gadjah Mada.

SUPARTO, R.S.

1978 - Proceedings of Symposium on the LongTerm Effects of Logging in Southeast Asia. BIOTROP (Regional Center for Tropical Biology) Special Publication N. 3, Bogor, Indonesia.
SYNNOTT, T.J.

1977 - Monitoring Tropical Forests: A Review with Special Reference to Africa. Paris, France. Monitoring and Assessment Research Center. Scientific Committee on Problems of Problems of the Environment, International Council of Scientific Unions.

TINAL, U. \& BALENEWAN, J.L.

1974 - A Study of Mechanical Logging Damage After Selective Cutting in the Lowland Dipterocarp Forest of East Kalimantan. Bogor, Indonesia. Regional Center for Tropical Biology (BIOTROP).

\section{UNESCO}

1978 - Tropical Forest Ecosystems: A State-otof-Knowledge Report. Paris, France. Natural Resources Research XIV, Unesco.

WATTERS, R.F.

1971 - Shifting Cultivation in Latin America. Rome, Italy. Food and Agriculture Organiza. tion.

WHITMORE, T.C.

1975 - Tropical Rain Forests of the Far East. Oxford, U.K. Clarendon Press.

(Aceito para publicação em $23 / 06 / 80$ ) 